OPEN ACCESS

Citation: Verónica Farreras, Laura Abraham (2020) Valuation of Viticultural Adaptation to Climate Change in Vineyards: A Discrete Choice Experiment to Prioritize Trade-Offs Perceived by Citizens. Wine Economics and Policy 9(2): 99-112. doi: 10.36253/web-9823

Copyright: () 2020 Verónica Farreras, Laura Abraham. This is an open access, peer-reviewed article published by Firenze University Press (http:// www.fupress.com/wep) and distributed under the terms of the Creative Commons Attribution License, which permits unrestricted use, distribution, and reproduction in any medium, provided the original author and source are credited.

Data Availability Statement: All relevant data are within the paper and its Supporting Information files.

Competing Interests: The Author(s) declare(s) no conflict of interest.

\section{Valuation of Viticultural Adaptation to Climate Change in Vineyards: A Discrete Choice Experiment to Prioritize Trade-Offs Perceived by Citizens}

\author{
Verónica Farreras ${ }^{1,2}$, Laura Abraham ${ }^{3, *}$ \\ ${ }^{1}$ Instituto Argentino de Nivología, Glaciología y Ciencias Ambientales (CCT-CONICET- \\ Mendoza). Av. Ruiz Leal s/n Parque General San Martín.Mendoza - Argentina. CP 5500. \\ Email:vfarreras@mendoza-conicet.gob.ar \\ ${ }^{2}$ Universidad Nacional de Cuyo, Facultad de Ciencias Económicas, M5502JMA Mendoza, \\ Argentina \\ ${ }^{3}$ Universidad Nacional de Cuyo, Facultad de Ciencias Agrarias, Almirante Brown 500, \\ Chacras de Coria, Luján de Cuyo, CPA M5528AHB Mendoza, Argentina. Email: labra- \\ ham@fca.uncu.edu.ar \\ ${ }^{\star}$ Corresponding author
}

\begin{abstract}
On a climate change scenario, a discrete choice experiment was applied to elicit the trade-off values for three environmental impacts of current viticultural management practices in vineyards of Mendoza, Argentina. Water availability for other uses was found to be the most concerning topic for the population, followed by use of chemical fertilizers and then by use and conservation of biodiversity. An increase of one percentage point in water availability was estimated to add each citizen on average 13.05 Argentinean pesos - 0.74 US dollars - per year in terms of increased welfare, a figure equivalent to the welfare drop a citizen would experience after an increase of 1.45 percentage points in the use of chemical fertilizers annually per hectare, or a decrease of 2.69 percentage points in the use and conservation of biodiversity. These trade-off values may help policy makers, planners, regional managers, and ecologists to take social preferences into account in setting resource allocation priorities intended to support viticulture. This study approach provides a framework that could guide similar assessments in other regions.
\end{abstract}

Keywords: viticultural management practices, climate change, discrete choice experiment, human welfare effects of environmental-impact choices. 


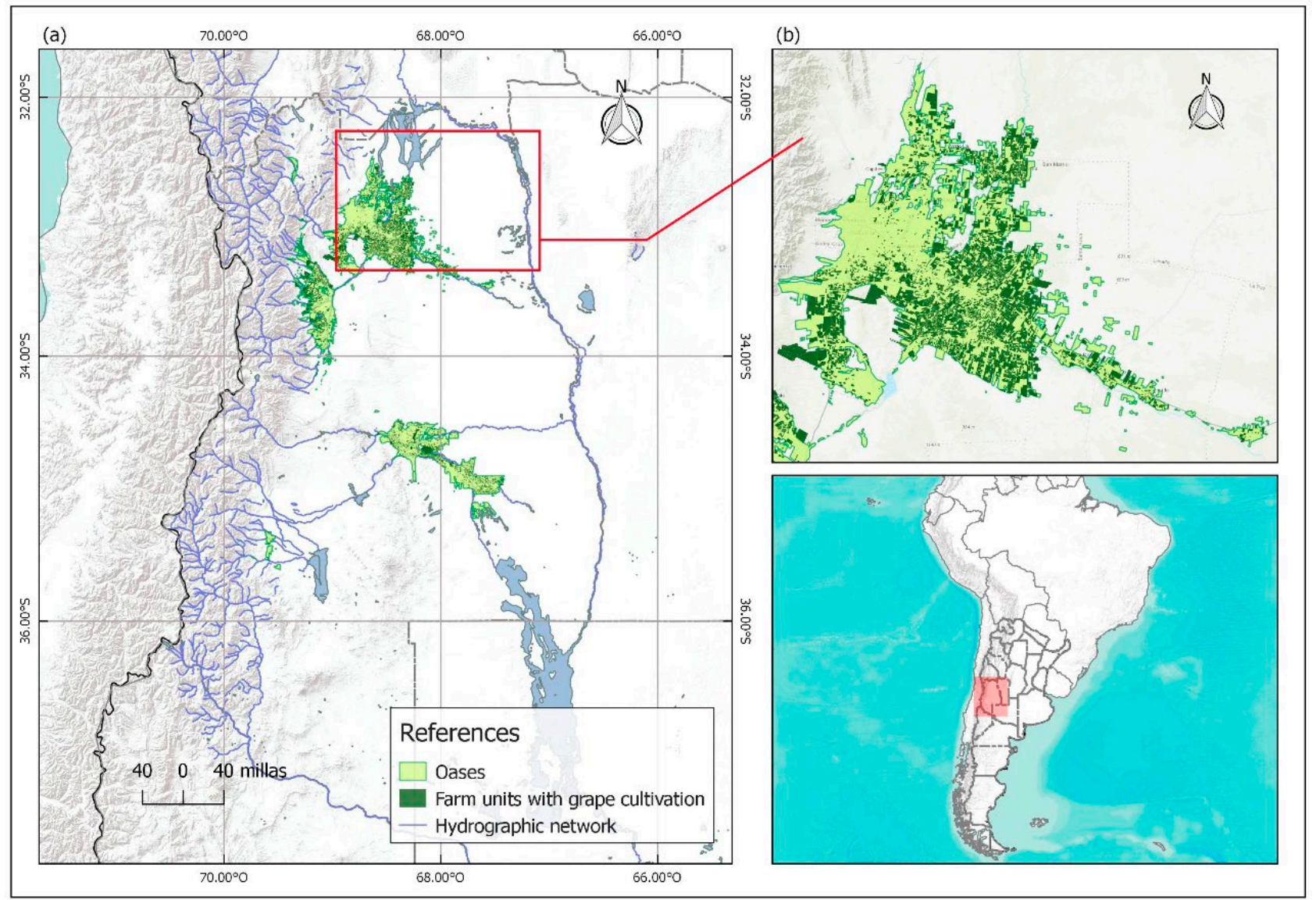

Figure 1. Farm units with grape cultivation (a) in the oases of Mendoza province and (b) in the Mendocinian Northern Oasis (source: Own elaboration based on data obtained from National Sanitary Registry of Agricultural Products (RENSPA) and cartography of the Territorial Environmental Information System (SIAT) and National Geographic Institute (IGN)). The darkened areas are farm units with grape cultivation.

in Argentina (INV, 2018). ${ }^{1}$ In Mendoza, viticulture has been developed, like in many other viticultural zones of the region, since the end of the XIX Century, initiated by European immigrants (Lacoste, 2003). Its green and vast vineyards are well known not only because of its productive economic value, but also because of its cultural and identifying values (Montaña, 2007).

The region is characterized by its arid and semiarid climate, with an annual average rainfall of 220 $\mathrm{mm}$. Due to the dry weather, water availability in Mendoza is a determining factor, most of the Mendocinian agricultural and urban areas are reduced to small portions of its territory (Figure 1. a: Oases and non-irrigated land). These oases were built upon an irrigation system of ditches and canals which strictly takes into account the topography of the place. This system makes the most of the water coming from the mountain rivers, whose

${ }^{1}$ One hectare contains approximately 2.47 acres. streamflow is a result of the fusion between the snow and the Andean glaciers (Morábito et al., 2007).

Vineyards, on average, use $45 \%$ of the water available in the oases of the province. About $53 \%$ is available for industrial use, public use -green spaces and urban trees- and watering of crops other than vineyards. The percentage of water supply for the population, currently estimated at $2 \%$, completes $100 \%$ of the water availability in the oases. ${ }^{2}$ The exploitation of irrigation water depends mainly on the irrigation system adopted. Almost $90 \%$ of the Mendocinian vineyards use the traditional surface irrigation system with an estimated irrigation efficiency of $39 \%$ for a furrow system with drain and $67 \%$ for a furrow system without drain. Whilst in

\footnotetext{
${ }^{2}$ However, to the effects of the empirical application developed below, the percentage of water supply for the population is not contemplated within the $53 \%$ of water available in the oases after using it for the vineyards, given that Mendoza Water Law 1884, still applicable, prioritizes population's supply against any other uses (DGI, 2016).
} 
the rest of the vineyards, the estimated efficiency varies between $82 \%$ and $90 \%$ as a result of the implementation of water-saving technologies such as the drip irrigation system (Morábito et al., 2007; Schilardi et al., 2015).

In the last seven years, there has been a substantial deficit in the water balance of the mountain rivers in Mendoza (Castex et al., 2015). This hydrological deficit is the result of a decrease in the snowfall and the retreat of the glaciers caused by an average global warming between 0.6 and $0.7^{\circ} \mathrm{C}$ (IPCC, 2013; Boninsegna, 2014; Poblete and Minetti, 2017). In the upcoming decades, this phenomenon is expected to aggravate as a consequence of a predictable increase in the average temperatures of the Central Andes (Cabré et al., 2016). This increase in temperature will drastically raise the regional evapotranspiration, it will alter the relations between rainfall and snowfall and it will modify the seasonal distribution of the runoff of the mountain rivers (Villalba, 2009; Lauro et al., 2019). Global warming and the current and future hydrological deficit will, undoubtedly, have important consequences on the availability of this resource unless there is a more efficient use of the water coming from the mountain rivers (Castex et al., 2015). A decrease in the availability of water will probably lead to an increased competition in the oases, compromising the current vineyard surface. That is, unless vineyards can make use of the water destined for other purposes (industrial use, public use - green spaces and urban trees - and the watering of crops other than vineyards; hereinafter, water availability for other uses).

In line with global warming, weather simulations indicate that by the end of the present century there will be changes in the rainfall patterns on the plains located at the foot of the Andes (Boninsegna, 2014; Deis et al., 2015). An important increase in the frequency of summer precipitations is expected, mostly associated with severe convective storms (Castex et al., 2015; Cabré et al., 2016). The effect of rainfall is complex since crops respond differently depending on the type of precipitation and the soil management practices. Practices like applying manure and compost and the use of cover crops provide nutrients and organic matter, improving the structure and fertility of the soil (Miglécz et al., 2015). Experimental studies in the vineyards of Mendoza have reported benefits in the conservation of the soil as a result of cover crops used as green manure (Uliarte et al., 2013; Martínez et al., 2018; among others). However, the vast majority of the vineyards in Mendoza keeps their soils without vegetation cover throughout most of the year. More intense rainfall, as predicted for the upcoming years, can contribute to soil loss, reducing its nutrient content and organic matter. This reduc- tion decreases the size and stability of the soil aggregates and, together with the lack of vegetation cover, reduces water infiltration and increases superficial runoff (Powlson et al., 2011). All of this leads to soil erosion and an increase use of fertilizers in an attempt to keep the same crop yield (Pérez Vázquez and Landeros Sánchez, 2009). Currently in Mendoza, it is estimated that per year per hectare, an average of $80 \%$ of nutrients replenishment in the vineyards is achieved with the use of chemical fertilizers (van den Bosch, 2017). In the upcoming years, an increase in the use of chemical fertilizers in order to avoid a decrease in crop yield is expected as a result of the current soil management practices and the predictable changes in the frequency and intensity of the precipitations on the plains. However, the overuse of fertilizers can cause groundwater contamination from infiltration of fertilizers or carry-over contamination of fertilizers to surface water course (Meier et al., 2015). There have been reports of cases of water contamination caused by nitrates associated with excessive use of fertilizers in crops on the Central Oasis (Morábito et al., 2011; Salatino et al., 2017; among others).

Field studies show that global warming and global $\mathrm{CO}_{2}$ concentration have an effect on the population dynamics of the organisms that attack the crops as well as on their natural enemies (Hamada and Ghini, 2011; Karuppaiah and Sujayanad, 2012; among others). Vázquez (2011) has reported an alteration on the population dynamics of common pests as well as changes in their period of emergence, appearance of new pests and a reduction of natural enemies. This shows that global warming together with concentration of $\mathrm{CO}_{2}$ can cause phytosanitary problems and reduce the efficiency of the chemical control methods. In Mendoza, this phenomenon can be aggravated as a consequence of a raise in summer precipitations. Traditional crops such as vineyards can be affected by a higher occurrence of cryptogamic diseases (Villalba, 2009; Deis et al., 2015).

The use and conservation of biodiversity in crops not only make them less vulnerable to weather variations, but also can contribute to an effective control of pests and diseases through its natural or biological management (Nicholls Estrada, 2008). A diverse and complex crop system facilitates the necessary environmental conditions for the development of pests' natural enemies, making the agroecosystem generate its own natural protection (Rolando et al., 2017). It is estimated that, in Mendoza, only $2 \%$ of vineyards cultivated area utilizes and conserves biodiversity with cover crops and patches of native vegetation, which are maintained to provide habitat for natural enemies and local fauna (SENASA, 2017). This indicates that pesticides employed 
for the control of pests and diseases are more widely used than biological management practices. It is foreseen that in the next few years there will not be any significant changes in the use and conservation of biodiversity on the vineyards cultivated area of Mendoza, despite being widely well documented in the literature that the massive use of pesticides may reduce environmental quality (Turgut, 2007; Di Lorenzo et al., 2018; among others) and decrease the species diversity in the agroecosystems, modifying their stability and resilience (see, among others, Moonen and Bàrberi, 2008; Kremen and Miles, 2012).

Consequently, and in line with the above-mentioned literature, viticulture in the region faces new challenges due to global warming that must be considered in the design of its agricultural practices. Lower water availability for other uses, increased use of chemical fertilizers, and a non-significant change in the use and conservation of biodiversity are three of the most pronounced and environmentally concerning consequences of nonadaptive management practices to climate change in the vineyards of Mendoza.

According to the aforementioned results conducted on the vineyards of Mendoza (Uliarte et al., 2013; Castex et al., 2015; Martinez et al., 2018) and the current knowledge on the efficiency of the irrigation methods (Morábito et al., 2007; Schilardi, 2015), on changes in the precipitation patterns (Boninsegna, 2014; Deis et al., 2015), and on population dynamics of pests, diseases and natural enemies (Hamada and Ghini, 2011; Vázquez, 2011; Deis et al., 2015), we hypothesised a possible temperature-change scenario by 2050 , which we will refer to as the "do-nothing" or "business-as-usual" (BAU) situation. Considering the three mentioned variables - water availability for other uses, use of chemical fertilizers, and use and conservation of biodiversity - the changes from current average values to new values in 30 years' time were estimated subject to: (i) an increase in annual mean temperature by $2^{\circ} \mathrm{C}$, (ii) a rise in precipitations on the plains from $200 \mathrm{~mm}$ to $250 \mathrm{~mm}$ per year, and (iii) a 10\% decrease in snow accumulation in the Andes per year -figures in the medium range of the predicted change reported by multiple general circulation models for the region over the period of 20712100 (IPCC 2013; Boninsegna, 2014; Cabré et al., 2016; Poblete and Minetti, 2017).

Based on moderate interpretation of the above-mentioned literature and on expert opinions on viticulture and agricultural economics, the BAU situation assumed the following changes: the percentage of water availability for other uses, currently averaging about $53 \%$ in the Mendocinian oases, will drop to approximately $41 \%$; chemical fertilizers, currently representing every year on average $80 \%$ of nutrients replenishment per hectare of vineyard, will raise to $95 \%$; and finally the percentage of vineyards cultivated area that utilizes and conserves biodiversity, currently estimated on $2 \%$, will not register any significant changes, only reaching $3 \%{ }^{3}$

Nowadays, however, the human-welfare effects of these possible environmental changes are unknown. The information on the social significance of these possible changes can be useful for those involved in making decisions and may be considered in setting resource allocation priorities intended to support viticultural practices for climate change adaptation. In order to explore this, a discrete choice experiment valuation exercise was conducted to elicit the trade-offs perceived by Mendocinian citizens for changes in water availability for other uses, use of chemical fertilizers, use and conservation of biodiversity, and the willingness to pay for the adaptation of viticultural management practices to climate change. With this method the importance of these environmental changes can be expressed in monetary units and the extent to which citizens are willing to consent one change for another can be elicited (Hanley et al., 2002; Hensher et al., 2005; among others).

\section{DISCRETE CHOICE EXPERIMENT}

The label "discrete choice experiment" concerns to a survey-based valuation method consistent with welfare economic theory (Jones and Pease, 1997; Bennett and Blamey, 2001). This method, which belongs to the family of stated preference methods, describes a hypothetical market with details of the good to be considered (Carson and Louviere, 2011). The good details encompass some of its characteristics, known as attributes. Depending on the proposed action, the attributes can differ in their quantity or quality level. Different level combinations of attributes, alongside with a suggested payment, set up an alternative. In a discrete choice experiment, respondents are presented with a series of alternatives -usually called choice set, comprising BAU and two or more alternatives. Then they are asked to choose their most preferred alter-

\footnotetext{
${ }^{3}$ The decrease in the availability of water for other uses was estimated by considering that both current cultivated vineyard area and actual average percentage of irrigation efficiency will not register any significant changes during the next 30 years (Morábito et al., 2007; Schilardi et al., 2015; DGI, 2016). The increase in chemical fertilizers was estimated according to experts' opinions based on grape production models generated by the National Institute of Agricultural Technology (van den Bosch, 2017). The change in the use and conservation of biodiversity was estimated using the local trend in organic viticulture certification in Mendoza (SENASA, 2017).
} 
native (Hanley et al., 2002). A respondent can confront several successive choice sets throughout interview. In order to interpret the results in welfare economics terms, the BAU alternative must be included in each choice sets.

The discrete choice experiment is based on Random Utility Maximization (RUM) models (McFadden, 1973). A succinct methodological description is provided below, whilst a more comprehensive one can be found in Farreras et al. (2017).

Under the RUM framework, the utility function for each respondent has the form:

$U_{i j}=V_{i j}+\varepsilon_{i j}$

Where $U_{i j}$ is individual $i$ 's utility from choosing alternative $j, V_{i j}$ is the deterministic component of utility, and $\varepsilon_{i j}$ is a stochastic element that denotes unobservable motivates on individual choice (Manski, 1977). Usually, $\varepsilon$ is assumed to be independent and identically distributed (iid) across alternatives and individuals.

The condition for individual $i$ choosing a given alternative $j$ over any alternative option $k$ belonging to the set of alternatives $A$, can be expressed in probability terms, $P$, as:

$P_{i j}=P\left\{V_{i j}+\varepsilon_{i j}>V_{i k}+\varepsilon_{i k} ; \forall \mathrm{k} \neq \mathrm{j} \in \mathrm{A}\right\}$

The choice probabilities can be predicted using different models. Most often, choice probabilities are estimated using the Mixed Logit (ML) model. The most straightforward derivation, and most widely used in recent applications, is based on random coefficients (Train, 2009). Given that choice probabilities cannot be calculated accurately, they are approximated through simulation (Hensher and Greene, 2003).

\section{EMPIRICAL APPLICATION}

\subsection{Choice Sets}

Alternatives were defined by three non-monetary attributes - water availability for other uses, use of chemical fertilizers, and use and conservation of biodiversity -, and a monetary attribute in the form of an annuity to finance the adaptation of viticultural management practices to climate change.

Each attribute displayed four levels as shown on Table 1. The levels of water availability for other uses were described as an average percentage of water available in the oases for industrial use, public use - green spaces and urban trees - and the watering of crops other than vineyards. Likewise, the levels of use and conservation of biodiversity were also expressed in percentages and were defined as the average percentage of the vineyards cultivated area with native vegetation strips and cover crops that promote the biological control of pests and diseases. The levels of both attributes were distributed between the expected values in the BAU situation and the values above the BAU levels. The levels of use of chemical fertilizers were also expressed in percentages and were defined as the average percentage of nutrients

Table 1. Attributes and levels used in the choice questionnaire.

\begin{tabular}{|c|c|c|}
\hline Attribute & Description & Levels \\
\hline Water availability for other uses & $\begin{array}{l}\text { The average percentage of water that is available in oases for } \\
\text { industrial use, public use -green spaces and urban trees- and other } \\
\text { irrigated crops other than vineyards in } 30 \text { years' time. }\end{array}$ & $\begin{array}{l}41 \% \text { (business-as-usual) } \\
53 \% \text { (current level) } \\
65 \% \\
76 \%\end{array}$ \\
\hline Use of chemical fertilizers & $\begin{array}{l}\text { The average percentage of nutrients replaced with chemical } \\
\text { fertilizers in the vineyards, per year per hectare in } 30 \text { years' time. }\end{array}$ & $\begin{array}{l}\quad 95 \% \text { (business-as-usual) } \\
\quad 80 \% \text { (current level) } \\
50 \% \\
\quad 25 \%\end{array}$ \\
\hline Use and conservation of biodiver & $\begin{array}{l}\text { The average percentage of vineyards cultivated area with native } \\
\text { vegetation strips and cover crops that promote the biological control. } \\
\text { of pests and diseases in } 30 \text { years' time. }\end{array}$ & $\begin{array}{l}3 \% \text { (business-as-usual) } \\
\quad 10 \% \\
\quad 25 \% \\
50 \%\end{array}$ \\
\hline $\begin{array}{l}\text { Annual payment subject to } \\
\text { adjustment for inflation }^{\dagger}\end{array}$ & $\begin{array}{c}\text { The annual payment required per household over the next } 30 \text { years } \\
\text { to finance the adaptation of viticultural management practices to } \\
\text { climate change. }\end{array}$ & $\begin{array}{ll}\text {. } & 600 \text { Argentinean pesos } \\
\text {. } & 400 \text { Argentinean pesos } \\
\text {. } & \text { 0 Argentinean pesos (business- } \\
\text { as-usual and current level) }\end{array}$ \\
\hline
\end{tabular}

${ }^{\dagger}$ Average exchange rate in spring 2017: 1 US dollar equals 17.54 Argentinean pesos. 


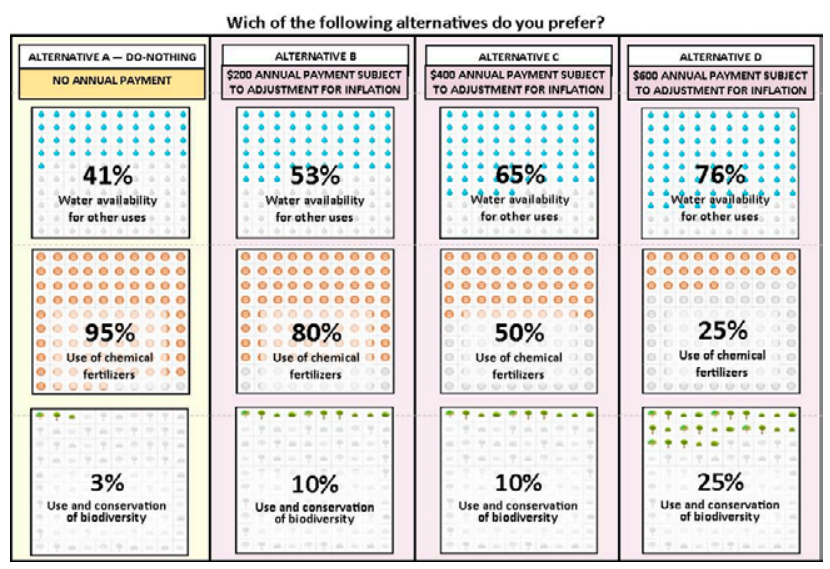

Figure 2. Example of a choice set presented to respondents.

that are replenished in the vineyards, each year per hectare, with chemical fertilizers. The levels of use of chemical fertilizers for scenarios different to BAU were defined below $95 \%$. The levels of BAU for the non-monetary attributes reflected the estimated situation in 30 years' time as a result of the use of non-adaptive management practices to climate change in Mendocinian vineyards, whilst the rest of the levels could be reached through the adaptation of viticultural practices to climate change. Focus groups confirmed that the temporal horizon of 30 years was perceived as reasonable and did not show any credibility problems.

The levels of payment were determined based on different focus groups in which the participants stated the maximum quantity of money they would be willing to pay for the different scenarios. The extra cost for "donothing" was zero. The monetary levels were expressed in Argentinean pesos subject to adjustment for inflation, to be paid per household each year, during the next 30 years.

There were $81\left(3^{4}\right)$ possible combinations of attribute levels or different alternatives, excluding the BAU levels, given that this situation does not vary. Since this universe was large, a statistically efficient choice design combining the attribute levels into alternatives and choice sets was constructed using NGENE (ChoiceMetrics, 2014), (Table 1). A D-optimal fractional factorial design consisting of 27 alternatives was identified. The alternatives were randomly grouped into 9 blocks of three alternatives plus BAU. Each block of four alternatives corresponds to a choice set. The efficiency for the final design expressed as the Bayesian D-error was 0.00148. A pilot exercise, used to complete the design process, confirmed that random combinations of the attribute levels posed no problems to participants and ensured the choice task adequacy.
The final version of the questionnaire included three different choice sets, which were randomly presented to each individual. Respondents were asked to pick within the choice set the alternative they preferred the most. Figure 2 reproduces a typical choice set. ${ }^{4}$

\subsection{Questionnaire}

The first part of the questionnaire focused on the presentation of the attributes. It described the current average level of each non-monetary attribute -water availability for other uses, use of chemical fertilizers, and use and conservation of biodiversity- in the Mendocinian oases and the most reliable prediction of the average levels of each attribute in 30 years' time (based on the working hypothesis that predicts a raise in temperature and annual precipitations of $2^{\circ} \mathrm{C}$ and $50 \mathrm{~mm}$, respectively and a $10 \%$ snowfall reduction) (Table 1 ). Hence, the questionnaire showed, in the first place, the expected change in the three non-monetary attributes under the "do-nothing" or BAU situation.

Afterwards, respondents were explained that with the adaptation of viticultural practices to climate change, the BAU situation could be modified. These practices included the sustainable agricultural management of water, soil and biodiversity such as the implementation of water-saving technologies, the substitution of chemical fertilizers for organic manure and cover crops used as green manure that additionally would allow, together with the conservation of native vegetation strips, the vineyards to generate its own protection against pests and diseases. Three alternative levels to BAU levels were presented for each non-monetary attribute indicating that the level each one of them would finally reach would depend on the quantity of money destined to finance the adaptation of the viticultural practices to climate change. In order to further familiarize individuals with possible levels of change, and check for satiation within the levels segment, participants were then asked to indicate the preferred attribute level, regardless of the cost.

After the introduction of non-monetary attributes, the monetary compensation was described. It was stated that the local government was considering the possibility of financing the adaptation of viticulture to climate change. It was explained that the degree of adaptation would depend on the quantity of resources allocated to this end, which in turn would depend on the answers to the questionnaire. If, on average, the answers indi-

\footnotetext{
${ }^{4}$ Given the sample size, each alternative was seen by an average of 70 respondents in the whole survey.
} 
cated that people were willing to pay some money for the adaptation of the viticultural practices to climate change, then the payments would be obligatory and would be charged annually to the citizens through a council tax. Some possible alternatives on the payment vehicles were tested on different focus groups. It was confirmed that the obligatory payment gathered by the council city through its tax was reasonable, credible and easily accepted by the interviewees; whilst other alternatives on payment vehicles such as direct payment to an organization created to this end caused rejection for its lack of credibility.

The central part of the questionnaire focused on the choice tasks and a set of debriefing questions. The third and last part of the questionnaire was designed to gather socioeconomic data, such as income, gender, age, and level of formal education, among others.

The survey was carried out in spring 2017. A representative sample of the residents of the Northern Mendocinian Oasis - which concentrates $58.20 \%$ of the total Mendocinian farm units with grape cultivation and in which more than half the total population of the province lives - was interviewed face to face in the respondents' households (Figure 1. b). According to the National Institute of Statistics and Censuses (INDEC, 2010), the Northern Oasis has a population close to one million people. The total number of interviewees between the age of 24 and 80 was 226 . The sample included residents in cities of more than 10,000 people randomly drawn after weighting cities according to their population size - and were interviewed in blocks of 6 . The selection of individuals within a block was conducted through a random-route procedure to find a household and then, within the household, a particular individual to fulfil a specific quota for age and gender. Around $90 \%$ of the people chosen accepted to be interviewed. All of them completed the choice tasks, which resulted in 678 valid observations -three sets of choice per person. From a social economic point of view, the sample and composition of the population were relatively similar (Table 2).

The questionnaire was handed out in paper format and read by the interviewer. Each questionnaire came along with a set of coloured cards, which showed the attributes being valued. Each interview took approximately 30 minutes and no signs of fatigue or other obvious problems were detected.

\section{RESULTS}

An ML model was determined to detect the relation between the levels of the attributes and the probability of
Table 2. Sample and population composition in the Northern Oasis.

\begin{tabular}{lcc}
\hline $\begin{array}{l}\text { Gender and age } \\
\text { groups }\end{array}$ & $\begin{array}{c}\text { Northern Oasis } \\
(\%)\end{array}$ & $\begin{array}{c}\text { Sample } \\
(\%)\end{array}$ \\
\hline Women & $52.63 \%$ & $54.21 \%$ \\
Age & $16.59 \%$ & $16.82 \%$ \\
$24-35$ & $14.71 \%$ & $13.55 \%$ \\
$36-49$ & $13.85 \%$ & $14.49 \%$ \\
$50-65$ & $5.47 \%$ & $6.54 \%$ \\
$66-75$ & $2.01 \%$ & $2.80 \%$ \\
$76-80$ & $47.37 \%$ & $45.79 \%$ \\
\hline Men & $16.34 \%$ & $18.22 \%$ \\
Age & $13.54 \%$ & $10.75 \%$ \\
$24-35$ & $11.99 \%$ & $12.15 \%$ \\
$36-49$ & $4.18 \%$ & $2.34 \%$ \\
$50-65$ & $1.32 \%$ & $2.34 \%$ \\
$66-75$ & Argentinean pesos (at & Argentinean pesos \\
$76-80$ & 2017 prices) & (at 2017 prices) \\
\hline Income ${ }^{\ddagger}$ & $27,019{ }^{\S}$ & 24,030 \\
& &
\end{tabular}

$\dagger$ INDEC 2010

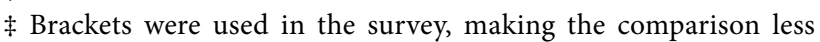
accurate between the average monthly income of the Argentinean urban agglomerations and that of the sample.

$\S$ Average monthly household income in the fourth quarter of 2017, according to INDEC 2017.

the interviewees choosing certain alternatives. The specification of the ML model requires certain characteristics such as the selection of the parameters -attributes- that are going to be considered random and the distribution supposed to them. In this way, it was considered, in the first place, that the preferences of the interviewees for the three non-monetary attributes were heterogeneous and followed a triangular distribution whilst the preferences for the monetary attribute were considered homogeneous. ${ }^{5}$ However, the standard deviations of the non-monetary attribute distributions were not statistically significant, which shows that the preferences for these variables were homogeneous among the individuals of the sample (Table 3). The three non-monetary and monetary variables entered the regression expressed in the units of the respective attributes as they were described in Table 1.

The coefficient signs were as expected and most of the variables were statistically significant with a $95 \%$ lev-

\footnotetext{
${ }^{5}$ Due to the higher probability of occurrence that some of the levels showed in relation to others considered. For the attributes water availability for other uses and use and conservation of biodiversity, the higher levels were the most selected ones within the range considered. Whilst for the attribute use of chemical fertilizers, the lower levels were the most chosen ones.
} 
Table 3. Results of the mixed logit regression analysis.

\begin{tabular}{lc}
\hline Variable & $\begin{array}{c}\text { Coefficient } \\
\text { (Standard Error) }\end{array}$ \\
\hline Random parameters in utility functions & \\
Water availability for other uses & $0.02062496^{* * *}$ \\
& $(0.00586975)$ \\
Use of chemical fertilizers & $-0.01422602^{* * *}$ \\
Use and conservation of & $(0.00289968)$ \\
biodiversity & $0.00767425^{\star}$ \\
\hline
\end{tabular}

Non-random parameters in utility functions

$\begin{array}{lc}\text { Annual payment } & -0.00158077^{* * *} \\ & (0.00042721) \\ \text { Income A } & -0.50662382^{* *} \\ & (0.23111555) \\ \text { Gender A } & -0.48969585^{* *} \\ & (0.24946993) \\ \text { Age A } & 0.02142159^{* * *} \\ & (0.00694294)\end{array}$

Derived standard deviations of parameter distributions

Water availability for other uses

0.06695391

$(0.04430034)$

$0.620393 \mathrm{D}-04$

Use of chemical fertilizers

$(0.02512014)$

0.00016680

Use and conservation of

(0.03114923)

biodiversity

$-798.5422$

Log likelihood function

.131664

Pseudo-R

642

NB: $6 \%$ of respondents chose the BAU situation (annual payment of 0 pesos) quoting reasons other than lack of value for the adaptation of viticulture to climate change, which could be considered as protests. After removing those observations, the quantitative analysis was performed on a subset of 214 respondents.

$\dagger$ Estimates were obtained using 1,000 random draws to simulate the sample likelihood.

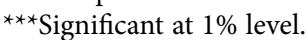

${ }^{* *}$ Significant at $5 \%$ level.

${ }^{*}$ Significant at $10 \%$ level.

el of confidence. The positive sign of the coefficients of water availability for other uses and of use and conservation of biodiversity shows that Mendocinian citizens tend to prefer higher levels of these attributes to lower levels. This implies that the alternatives with higher percentages of water availability for other uses and of use and conservation of biodiversity are more likely to be chosen. On the contrary, the coefficient signs of use of chemical fertilizers and of payment were negative, which shows that higher levels of these attributes decrease the population welfare.
Since the socioeconomic variables of the respondent do not vary over alternatives, they can only enter the model if they are specified in ways that create differences in utility over alternatives (Train, 2009). With 4 alternatives per choice set, one alternative-specific coefficient of income, gender and age variables entered the model, where three of the coefficients were normalized to zero (i.e., the three non-BAU alternatives were left out). The income data were collected in the survey using nine categories: no direct income; $<8,060$ Argentinean pesos; $8,060-12,000 ; 12,001-17,000 ; 17,001-22,000 ; 22,001-$ 30,$000 ; 30,001-40,000 ; 40,001-50,000$, and $>50,001$ Argentinean pesos. Thus, income entered the regression as a categorical variable reflecting the monthly earnings of the respondent's household, with A being the alternative-specific. While, the gender entered the regression as a dummy variable, we coded females to be 0 and males to be 1; with A being the specific alternative. Finally, the age entered the regression as a continuous variable reflecting the age in years of the individual, with A being the alternative-specific.

The negative sign of the coefficient of the variable income indicates that the interviewees with higher incomes are less likely of choosing option BAU, i.e., they are more likely to pay for the adaptation of the viticultural practices to climate change. On the other hand, the negative sign of the coefficient of the variable gender indicates that women are more prone to choose an alternative other than BAU. Conversely, the positive sign of the coefficient of the variable age denotes that the older the interviewees, the more likely they would choose option BAU. This suggests that, on average, women, younger respondents, and respondents with higher income obtain greater utility from the adaptation of viticulture to climate change.

Once estimated the parameters, the marginal values for each attribute can be inferred from the following relation of regression coefficient, $-\beta_{n} / \beta_{m}$, where $\beta_{n}$ is the coefficient of the attribute to be considered and $\beta_{m}$ represents the coefficient of the attribute in which units one wishes to express the value of the attribute of interest (Hensher et al., 2005). These values show the mean of the marginal values of the population, in the units of the variable in which change wants to be expressed - percentage points or Argentinian pesos at 2017 price subject to adjustment for inflation. The marginal values for each attribute are illustrated in Figure 3.

According to the respondents' perception, for example, in order to obtain an increase of one percentage point in the water availability for other uses, a representative Mendocinian citizen would, on average, be willing to consent (at most) an increase of 1.45 percentage points 

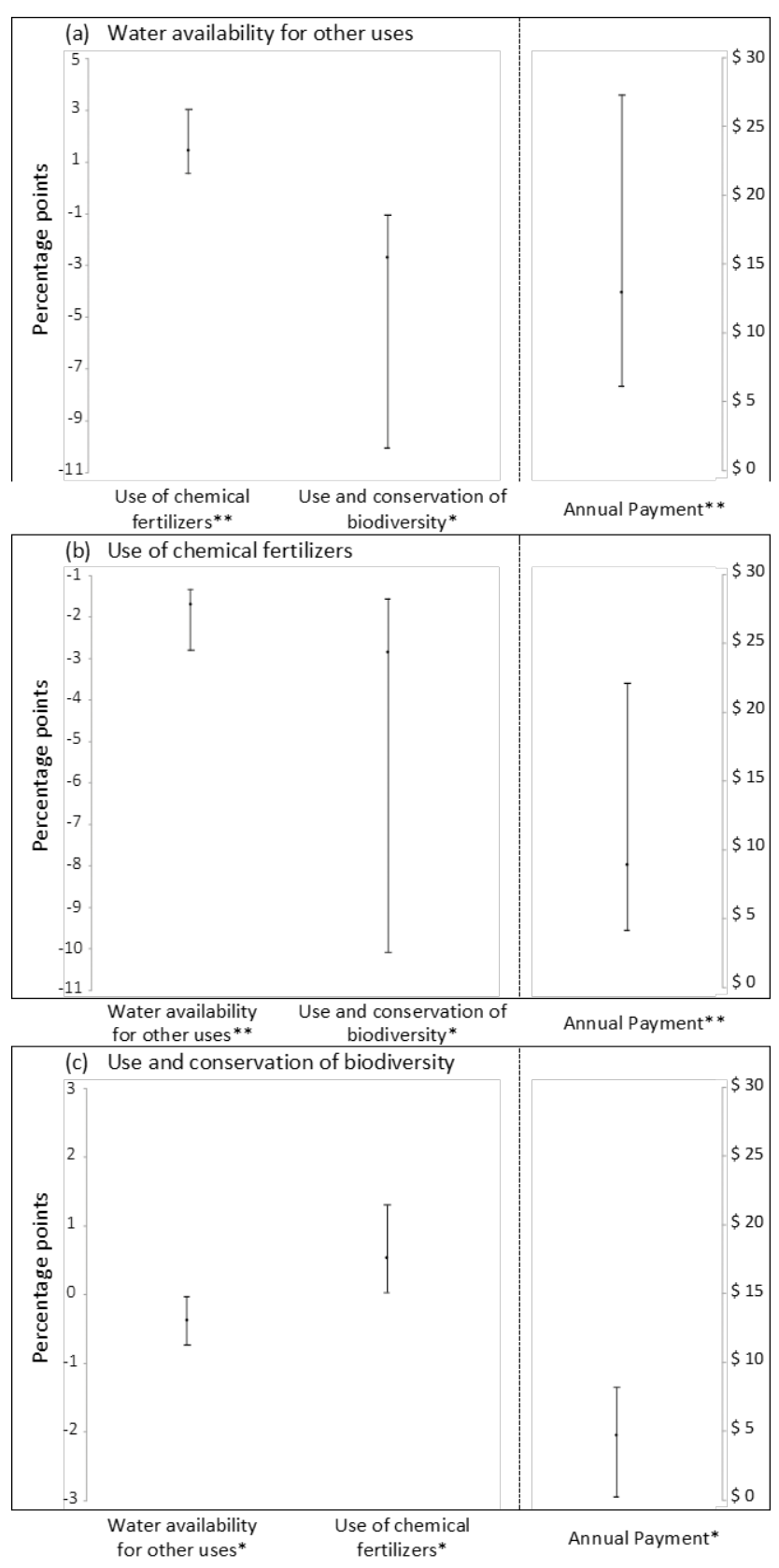

Attributes

in the use of chemical fertilizers, or a decrease of 2.69 percentage points in the use and conservation of biodiversity, or to pay per household (at most) 13.05 Argentinean pesos - 0.74 US dollars - annually during the next 30 years. The confidence intervals for the marginal value of each attribute were calculated using the Krinsky and Robb procedure (1986) with 3,000 repetitions.

Likewise, these marginal values can also be useful to elicit the trade-offs, as perceived by Mendocinian
Figure 3. Marginal values for each non-monetary attribute (equivalent to a one percentage point change). Values in relative units of attributes with their respective confidence intervals for (a) an increase of one percentage point in the water availability for other uses, (b) a decrease of one percentage point in the use of chemical fertilizers, and (c) an increase of one percentage point in the use and conservation of biodiversity. Non-monetary attributes are expressed as percentage points on the left-hand vertical axis, while the monetary attribute is expressed in Argentinean pesos (at 2017 prices subject to adjustment for inflation) on the right-hand vertical axis. (a) An increase in the water availability for other uses of one percentage point- e.g., from $41 \%$ to $42 \%$ - offsets (1) an increase, on average, in the use of chemical fertilizers of $1.45(0.55,3.02)$ percentage points, the figures in parentheses denoting the limits of the 95\% CI; (2) a decrease, on average, in the use and conservation of biodiversity of $2.69(1.05,10.05)$ percentage points, the figures in parentheses denoting the limits of the $90 \% \mathrm{CI}$; and (3) the equivalent, in terms of welfare, of an annual expenditure per household, on average, of $13.05(6.24,27.28)$ Argentinean pesos $[0.74(0.35,1.55)$ US dollars] over the next 30 years, the figures in parentheses denoting the limits of the $95 \%$ CI. (b) A decrease in the use of chemical fertilizers of one percentage point - e.g., from $95 \%$ to $94 \%$ - offsets (1) a decrease, on average, in the water availability for other uses of $0.68(0.33,1.80)$ percentage points, the figures in parentheses denoting the limits of the $95 \% \mathrm{CI}$; (2) a decrease, on average, in the use and conservation of biodiversity of $1.85(0.55$, 9.07) percentage points, the figures in parentheses denoting the limits of the $90 \% \mathrm{CI}$; and (3) the equivalent, in terms of welfare, of an annual expenditure per household, on average, of 9.00 (4.22, 22.09) Argentinean pesos $[0.51(0.24,1.26)$ US dollars] over the next 30 years, the figures in parentheses denoting the limits of the 95\% CI. (c) An increase in the use and conservation of biodiversity of one percentage point - e.g., from $3 \%$ to $4 \%$ - offsets (1) a decrease, on average, in the water availability for other uses of 0.37 $(0.03,0.73)$ percentage points, the figures in parentheses denoting the limits of the $90 \% \mathrm{CI}$; (2) an increase, on average, in the use of chemical fertilizers of $0.54(0.03,1.30)$ percentage points, the figures in parentheses denoting the limits of the $90 \% \mathrm{CI}$; and (3) the equivalent, in terms of welfare, of an annual expenditure per household, on average, of $4.85(0.39,8.27)$ Argentinean pesos [0.28 (0.02, $0.47)$ US dollars] over the next 30 years, figures in parentheses denoting the limits of the $90 \%$ CI.

$* * 95 \%$ confidence interval.

$\star 90 \%$ confidence interval. citizens, for expected changes if none or only some viticultural practices are adapted to climate change. Assuming a unitary price elasticity of demand, for example, the increased welfare that a citizen would experience, on average, as a result of an increase from $3 \%$ to $25 \%$ in the use and conservation of biodiversity is equivalent to the welfare drop he or she would experience after an increase from $80 \%$ to $91.85 \%$ in the use of chemical fertilizers. These social-welfare changes are inferred from Figure 3. 


\section{DISCUSSION AND CONCLUSIONS}

This research intends to contribute to a deeper and further discussion on the way of managing the relation between agriculture and the conservation of the environment and natural resources. On a climate change scenario, the monetary value of sustainable agricultural management practices in Mendocinian vineyards was estimated.

The valuation exercise results show that Mendocinian citizens are willing to pay for the adaptation of viticultural management practices to climate change. This result is in line with the findings of Riera et al. (2007), a study that elicited the trade-off values for three climatesensitive attributes - plant cover, fire risk, and soil erosion - of Mediterranean shrubland. They found that Catalan citizens were willing to finance programs that might mitigate climate-change impacts on shrublands. Arora et al. (2017) also reached similar findings for rice cultivation in India. Using the discrete choice experiment, they found that farmers were willing to pay a significant premium for reducing the abiotic stresses, such as droughts and flood, induced by climate change. Similar conclusions from climate change adaptation in cultivated areas were found by Waldman and Richardson (2018). They looked into the Malian farmers' valuation of hybrid-perennial sorghum technologies that might facilitate adaptation to climate change. Although not specifically dealing with climate change adaptation, SellersRubio and Nicolau Gonzalbez (2016) and Lanfranchi et al. (2019) found that individuals were willing to pay for implementation of sustainable wine production methods. Using a contingent valuation method, Sellers-Rubio and Nicolau Gonzalbez (2016) looked at the non-market value of these production methods in Spain, while Lanfranchi et al. (2019) estimated the willingness to pay of Sicilian consumers for a sustainable wine.

Our findings also suggest that, on average, women, younger respondents, and respondents with higher income are more prone to choose an alternative other than BAU. That is, they are more likely to be willing to pay for the viticultural adaptation to climate change, a result consistent with welfare economic theory and expectations. These findings have also been reported in several other studies which show consumer's general interest towards environmental-friendly wine production methods (see, among others, Sellers-Rubio and Nicolau Gonzalbez, 2016; Pomarici et al., 2018; Lanfranchi et al., 2019).

As well, our research provides results not only in monetary units, but also in the units of the other attributes considered (Figure 3). These trade-off values provide useful information for both private sector and policy makers. For instance, those involved in making deci- sions may wish to set resource allocation destined to finance viticultural practices prioritizing the balance among water availability for other uses, use of chemical fertilizers, and use and conservation of biodiversity, as expressed by citizens. Moreover, these social values expressed in monetary units can be useful for planners and regional managements to evaluate whether the benefits of a given policy outweigh its costs. Likewise, the results suggest that citizens are prepared to invest on sustainable agricultural management on private land, a result also found in Yao and Kaval (2010). Thus, the estimated values of the environmental impact reduction of viticulture may be useful not only for future government policy decision making, but also to be incorporated in the market goods price. For instance, the estimated value of an additional percentage point in the water availability for other uses could indicate the price premium that a citizen would, on average, be willing to pay (at most) for each wine glass produced with watersaving technologies. In this context indeed, an analysis of young consumers' preferences for wines labelled with a water saving claim was conducted by Pomarici $e t$ al. (2018). This study revealed that on average consumers are willing to pay an extra of half a dollar or more for water saving labelled wines. Others studies have also shown that consumers are willing to pay a premium price for wines with sustainable production characteristics (Barreiro-Hurlé et al., 2008; Mueller and Remaud, 2010; Schäufele and Hamm, 2017; among others).

Water availability for other uses was found to be the most concerning attribute for the population considering the expected changes under the "do-nothing" situation. This finding is consistent with the answers to an explicit question on the relative significance of the attributes. As show in Table 4, water availability for other uses was the attribute that three quarters of all respondents had in mind when deciding on the contingent choices. This information denotes a certain consistency with the results followed from marginal rate of substitution (Figure 3).

Even though there was not an explicit question that discloses the reason of this preference, the province of Mendoza has been on hydrological emergency for the last seven years. Hydrological emergency is an issue frequently mentioned on the news and the population is constantly being asked to make a rational and careful use of water. This result is also in line with the findings of Farreras and Lauro (2016), a study that dealt with the valuation of possible environmental waste landfills impacts in Mendoza. They used a discrete choice experiment to value different attributes - water quality, air quality, and vector-borne diseases -. Water quality was defined as the resource aptitude to be used in the fol- 
Table 4. Percentage of respondents that took into account this variable more than any other when deciding on the contingent choices.

\begin{tabular}{lc}
\hline Variable & Respondent consideration (\%) \\
\hline Water Availability for other uses & $75.59 \%$ \\
\hline Use of chemical fertilizers & $53.52 \%$ \\
\hline $\begin{array}{ll}\text { Use and conservation of } \\
\text { biodiversity }\end{array}$ & $50.23 \%$ \\
\hline Annual payment & $49.07 \%$ \\
Years $^{\dagger}$ & $21.30 \%$ \\
\hline
\end{tabular}

NB: Percentages do not add to $100 \%$ because respondents could select more than one answer.

${ }^{\dagger}$ The temporal horizon of 30 years for viticultural adaptation to climate change.

lowing possible uses: (i) domestic, (ii) agricultural, (iii) industrial, and (iv) recreational. An attribute in common between their paper and ours is that related to water availability, which was found to be the most valuable attribute.

Concerning biodiversity valuation, there is some disconcert reflected in the relatively modest statistical significance of this attribute. This seems to reflect a lack of a priori well-formed preferences of some respondents. Whereas some people were sure about the implications of changes in biodiversity to themselves, other respondents were not so sure. A similar conclusion has been reached by Lienhoop and MacMillan (2007), Szabó (2011), among others, who have reported the prevalence of unformed or ill-formed preferences for non-marketed public goods, such as biodiversity which is often complex and unfamiliar.

In short, this study displays that the welfare of Mendocinian citizens is expected to drop in line with the environmental impacts predicted to occur as a result of the non-adaptive viticultural management practices to climate change. The most socially concerning topic is water availability for other uses, followed by use of chemical fertilizers and then by use and conservation of biodiversity. From a social point of view, this result implies that agricultural practices that are more focused on sustainable water management are the ones that increase welfare to citizens the most. This information can be useful for policy makers, planners, regional managers, and ecologists in order to take social preferences into account in setting resource allocation priorities intended to support viticulture. Finally, this study approach provides a framework that could guide similar assessments in other regions.

\section{ACKNOWLEDGMENTS}

This work was supported by the Secretaría de Investigación, Internacionales y Posgrado, Universidad Nacional de Cuyo (Grant numbers 01/A039). We would like to thank the anonymous reviewers for their valuable comments, and Emilce Vaccarino for her help in drafting the map.

\section{REFERENCES}

Arora, A., Bansal, S., Ward, P.S., 2018. Do farmers value rice varieties tolerant to droughts and floods? Evidence from a discrete choice experiment in Odisha, India. Water Resour. Econ. 1-15. https://doi. org/10.1016/j.wre.2018.03.001

Barreiro-Hurlé, J., Colombo, S., Cantos-Villar, E., 2008. Is there a market for functional wines? Consumer preferences and willingness to pay for resveratrolenriched red wine. Food Quality and Preference 19, 360-371.

Bennett, J., Blamey, R., (eds.). 2001. The choice modelling approach to environmental valuation. Cheltenham, UK: Edward Elgar.

Boninsegna, J.A., 2014. Impacto del cambio climático en los oasis del oeste argentino. Ciencia e Investigación $64,45-58$.

Cabré, M.F., Quénol, H., Nuñez, M., 2016. Regional climate change scenarios applied to viticultural zoning in Mendoza, Argentina. Int. J. Biometeorol. 60, 13251340. https://doi.org/10.1007/s00484-015-1126-3

Carson, R.T., Louviere, J.J., 2011. A common nomenclature for stated preference elicitation approaches. Environmental and Resource Economics 49, 539-559. https://doi.org/10.1007/s10640-010-9450-x

Castex, V., Morán, E., Beniston, M., 2015. Water availability, use and governance in the wine producing region of Mendoza, Argentina. Environmental Science \& Policy 48, 1-8. https://doi.org/10.1016/j.envsci.2014.12.008.

ChoiceMetrics. 2014. Ngene 1.1.2. User Manual \& Reference Guide, Australia.

Deis, L., Rosas, M.I. De, Malovini, E., Cavagnaro, M., 2015. Climate change impact in Mendoza. Climate variation on the last 50 years. A view to grapevine physiology. Rev. FCA UNCuyo 47, 67-92.

DGI, 2016. Departamento General de Irrigación. Aquabook. Available from: http://aquabook.agua.gob.ar/ Accessed March 18, 2019.

Di Lorenzo, T., Cifoni, M., Fiasca, B., Di Cioccio, A., Galassi, D.M.P., 2018. Science of the Total Environ- 
ment Ecological risk assessment of pesticide mixtures in the alluvial aquifers of central Italy: Toward more realistic scenarios for risk mitigation. Sci. Total Environ. $644,161-172$. https://doi.org/10.1016/j.scitotenv.2018.06.345

Farreras, V., Lauro, C., 2016. Valoración económica de los efectos de la contaminación por vertido de residuos sólidos urbanos. El caso del aglomerado urbano del Gran Mendoza, Argentina. Gestión y Ambiente 19, 211-227. http://dx.doi.org/10.15446/ga.v19n2.54755.

Farreras, V., Riera, P., Salvador, P.F., 2017. Environmental valuation with periodical payments in high-inflation economies. An Argentinean case study. Ecological Economics 138, 56-63. https://doi.org/10.1016/j. ecolecon.2017.03.028.

Hamada, E., Gini, R., 2011. Impacts of climate change on plant diseases and pests in Brazil. Revista Mexicana de Ciencias Agrícolas 2, 195-205.

Hanley, N., Mourato, S., Wright, R.E., 2002. Choice Modelling Approaches: A Superior Alternative for Environmental Valuatioin? J. Econ. Surv. 15, 435-462. https://doi.org/10.1111/1467-6419.00145

Hensher, D., Greene, W.H., 2003. The mixed logit model: the state of practice and Warnings for the Unwary. Transportation (Amst). 30, 133-176. https://doi. org/10.1.1.195.1039

Hensher, D.A., Rose, J.M., Greene, W.H., 2005. Applied choice analysis: A primer. Cambridge, UK: Cambridge University Press.

INDEC, 2010. Instituto Nacional de Estadísticas y Censo. Censo Nacional de Población, Hogares y Vivienda en Argentina. Available from: https://www.indec. gob.ar/ftp/cuadros/poblacion/censo2010_tomo1.pdf Accessed November 28, 2018.

INDEC, 2017. Instituto Nacional de Estadísticas y Censo. Evolución de la distribución del ingreso. Cuarto trimestre de 2017. Available from: https://www.indec. gob.ar/uploads/informesdeprensa/ingresos_4trim 17 . pdf Accessed November 12, 2018.

INV, 2018. Instituto Nacional de Vitivinicultura. Informe anual de superficie 2017. Available from: https://www. argentina.gob.ar/inv/vinos/estadisticas/superficie/ anuarios Accessed January 29, 2019.

IPCC, 2013. Intergovernmental Panel on Climate Change. Climate change 2013: The physical science basis. Contribution of working group I to the Fifth Assessment Report of the Intergovernmental Panel on Climate Change. Stocker, T., Qin, D., Plattner, G.-K., Tignor, M., Allen, S., Boschung, J., Nauels, A., Xia, Y., Bex, V., Midgley, P. (eds). New York, USA: Cambridge University Press https://doi.org/10.1017/ CBO9781107415324.001
Jones, C., Pease, K., 1997. Restoration-based compensation measures in natural resource liability statutes. Contemporary Economic Policy 15, 111-122. https:// doi.org/10.1111/j.1465-7287.1997.tb00494.x

Karuppaiah, V., Sujayanad, G., 2012. Impact of climate change on population dynamics of insect pests. World J. Agric. Sci. 8, 240-246.

Kremen, C., Miles, A., 2012. Ecosystem Services in Biologically Diversified versus Conventional Farming Systems: Benefits, Externalities, and Trade-Offs. Ecology and Society 17(4), 40. http://dx.doi.org/10.5751/ ES-05035-170440

Krinsky, I., Robb, A.L., 1986. On Approximating the Statistical Properties of Elasticities. The Review of Economics and Statistics 68, 715-719. http://dx.doi. org/10.2307/1924536

Lacoste, P., 2003. El vino del inmigrante: los inmigrantes europeos y la industria vitivinícola argentina: su incidencia en la incorporación, difusión y estandarización del uso de topónimos europeos 1852-1980. Mendoza, Argentina: Consejo Empresario Mendocino.

Lanfranchi, M., Schimmenti, E., Campolo, M.G., Giannetto, C., 2019. The willingness to pay of Sicilian consumers for a wine obtained with sustainable production method: An estimate through an ordered probit sample-selection model. Wine Econ. Policy 8, 203-215. https://doi.org/10.1016/j.wep.2019.11.001

Lauro, C., Vich, A., Moreiras, S., 2019. Streamflow variability and its relationship with climate indices in western rivers of Argentina. Hydrological Sciences Journal 64, 607-619. https://doi.org/10.1080/0262666 7.2019 .1594820

Lienhoop, N., MacMillan, D., 2007. Valuing wilderness in Iceland: Estimation of WTA and WTP using the market stall approach to contingent valuation. Land Use Policy 24, 289-295. https://doi.org/10.1016/j.landusepol.2005.07.001

Manski, C., 1977. The structure of random utility models. Theory and Decision 8, 229-254. https://doi. org/10.1007/BF00133443

Martínez, L.E., Vallone, R.C., Piccoli, P.N., Ratto, S.E., 2018. Assessment of soil properties, plant yield and composition, after different type and applications mode of organic amendment in a vineyard of Mendoza, Argentina. Rev. la Fac. Ciencias Agrar. 50, $17-32$.

McFadden, D., 1973. Conditional logit analysis of qualitative choice behavior. In P. Zarembka. (ed.), Frontiers in Econometrics, 105-142. New York, USA: Academic Press.

Meier, M.S., Stoessel, F., Jungbluth, N., Juraske, R., Schader, C., Stolze, M., 2015. Environmental impacts of 
organic and conventional agricultural products e Are the differences captured by life cycle assessment? J. Environ. Manage. 149, 193-208. https://doi. org/10.1016/j.jenvman.2014.10.006

Miglécz, T., Valkó, O., Török, P., Deák, B., Kelemen, A., Donkó, Á., Drexler, D., Tóthmérész, B., 2015. Establishment of three cover crop mixtures in vineyards. Sci. Hortic. (Amsterdam) 197, 117-123. https://doi. org/10.1016/j.scienta.2015.09.017

Montaña, E., 2007. Identidad regional y construcción del territorio en Mendoza (Argentina): memorias y olvidos estratégicos. Bulletin de l'Institut Français d'Études Andines 36, 277-297. https://doi. org $/ 10.4000 /$ bifea. 3908

Moonen, A.C., Bàrberi, P., 2008. Functional biodiversity: An agroecosystem approach. Agric. Ecosyst. Environ. 127, 7-21. https://doi.org/10.1016/j.agee.2008.02.013

Morábito, J., Mirábile, C., Salatino, S., 2007. Eficiencia del riego superficial, actual y potencial, en el área de regadío del río Mendoza (Argentina). Ingeniería del Agua 14, 199-214. https://doi.org/10.4995/ ia.2007.2912

Morábito, J., Salatino, S., Bermejillo, A., Filippini, M., Campos, S., Nacif, N., Dediol, C., Medina, R., Maffei, J., Mastrantonio, L., Genovese, D, Stocco, A., September 2011. Contaminación antrópica en el río Tunuyán, Mendoza - Argentina: tendencias y escenarios futuros. In La Agricultura de Riego ante el Cambio Climático Global. Symposium held at the XVI Congreso Nacional de Irrigación, Culiacán, Sinaloa, México. Available from: https://www.ina.gov. ar/legacy/pdf/CRA-ryd-contaminacion-antropica.pdf Accessed November 28, 2018.

Mueller, S., Remaud, H. 2010. Are Australian wine consumers becoming more environmentally conscious? robustness of latent preference segments over time. In: Proceedings of the 5th International Academy of Wine Business Research Conference. Auckland, New Zealand.

Nicholls Estrada, C.I., 2008. Control biológico de insectos: un enfoque agroecológico. Medellín, Colombia: Universidad de Antioquia.

Pérez Vázquez, A., Landeros Sánchez. C., 2009. Agricultura y deterioro ambiental. Elementos 73, 19-25. Available from: http://www.elementos.buap.mx/ num73/pdf/19.pdf

Poblete, A., Minetti, J., 2017. ¿Influye el calentamiento global en la disminución de las nevadas en los Andes Áridos? Revista Universitaria de Geografía 26, 11-29. Available from: http://bibliotecadigital. uns.edu.ar/scielo.php?script=sci_arttext\&pid=S1852$42652017001100002 \& \operatorname{lng}=\mathrm{es} \& \mathrm{nrm}=\mathrm{iso}$
Pomarici, E., Asioli, D., Vecchio, R., Næs, T., 2018. Young consumers' preferences for water-saving wines: An experimental study. Wine Econ. Policy 7, 65-76. https://doi.org/10.1016/j.wep.2018.02.002

Powlson, D.S., Gregory, P.J., Whalley, W.R., Quinton, J.N., Hopkins, D.W., Whitmore, A.P., Hirsch, P.R., Goulding, K.W.T., 2011. Soil management in relation to sustainable agriculture and ecosystem services. Food Policy 36, S72-S87. https://doi.org/10.1016/j.foodpol.2010.11.025

Riera, P., Peñuelas, J., Farreras, V., Estiarte, M., 2007. Valuation of climate-change effects on Mediterranean shrublands. Ecological Applications 17, 91-100. https://doi.org/10.1890/1051-0761(2007)017[0091:VOC $\mathrm{EOM}] 2.0 . \mathrm{CO} ; 2$

Rolando, J.L., Turin, C., Ramírez, D.A., Mares, V., Monerris, J., Quiroz, R., 2017. Key ecosystem services and ecological intensification of agriculture in the tropical high-Andean Puna as affected by land-use and climate changes. Agric. Ecosyst. Environ. 236, 221-233. https://doi.org/10.1016/j.agee.2016.12.010

Salatino, S., Morábito, J., Bermejillo, A., Dediol, C., Stocco, A., Tapia, O., Miralles, S., Hernández, R., Mastrantonio, L., Genovese, D., Ortiz, N., 2017. Calidad de aguas y análisis de la contaminación en el Río Tunuyán Superior (Mendoza, Argentina) en el periodo 2007-2014. AUGMDOMUS 9, 67-82. Available from: https://revistas.unlp.edu.ar/domus/article/view/2410

Schäufele, I., Hamm, U., 2017. Consumers' perceptions, preferences and willingness-to-pay for wine with sustainability characteristics: a review. J. Clean. Prod. 147 (20), 379-394.

Schilardi, C., Rearte, E., Martín, L., Morábito, J., June 2015. Uniformidad de distribución del riego por goteo en vid: su impacto sobre los índices de vegetación, la cantidad y calidad de la producción. Caso de estudio en Mendoza, Argentina. In Agua, como Política de Estado. Symposium held at the XXV Congreso Nacional del Agua - CONAGUA 2015 -, Paraná, Entre Ríos, Argentina. Available from: https:// www.ina.gov.ar/legacy/pdf/Cra_7_Schilardi_Diagnostico.pdf Accessed January 29, 2019.

SENASA, 2017. Servicio Nacional de Sanidad y Calidad Agroalimentaria. Situación de la producción orgánica en la Argentina durante el año 2016. Available from: https://www.argentina.gob.ar/sites/default/files/5_situacin_de_la_po_en_la_argentina_2016.pdf Accessed November 15, 2018.

Sellers-Rubio, R., Nicolau-Gonzalbez, J.L., 2016. Estimating the willingness to pay for a sustain able wine using a Heckit model. Wine Economics and Policy 5 (2), 96-104. 
Szabó, Z., 2011. Reducing protest responses by deliberative monetary valuation: improving the validity of biodiversity valuation. Ecological Economics 72, 37-44. https://doi.org/10.1016/j.ecolecon.2011.09.025

Train, K., 2009. Discrete choice methods with simulation (2nd ed.). Available from: https://eml.berkeley.edu/ books/choice2.html

Turgut, C., 2007. The impact of pesticides toward parrotfeather when applied at the predicted environmental concentration 66, 469-473. https://doi.org/10.1016/j. chemosphere.2006.05.073

Uliarte, E., Ferrari, F., Montoya, M., Bonada, M., Ambrogetti, A.O., 2013. Viticultura orgánica. Aportes tecnológicos para el manejo ecológico de viñedos. In J.A. Ullé (ed.), Bases tecnológicas de sistemas de producción agroecológicos. Nodos Agrícola Ganadero, Agricultura Orgánica y Cultivos Perennes, 12-31. Buenos Aires, Argentina: Ediciones INTA.

van den Bosch, M. E., 2017. Márgenes Brutos de referencia de la producción de uvas en espalderos bajo con variedades de uva con destino enológico y reconocimiento varietal (finas). Ediciones INTA (Instituto Nacional de tecnología Agropecuaria) 1-8.

Vázquez, L., 2011. Cambio climático, incidencia de plagas y prácticas agroecológicas resilientes. In H. Ríos, D. Vargas and F. Funes-Monzote. (eds.), Innovación agroecológica, adaptación y mitigación del cambio climático, 75-101. Mayabeque, Cuba: INCA.

Villalba, R., 2009. Cambios climáticos regionales en el contexto del calentamiento global. (IANIGLA). CONICET Internal Publication (1), 11-14. Argentina, Mendoza.

Waldman, K.B., Richardson, R.B., 2018. Confronting Tradeoffs Between Agricultural Ecosystem Services and Adaptation to Climate Change in Mali. Ecol. Econ. 150, 184-193. https://doi.org/10.1016/j. ecolecon.2018.04.003

Yao, R.T., Kaval, P., 2010. Valuing biodiversity enhancement in New Zealand. International Journal of Ecological Economics and Statistics 16, 26-42. 